\title{
LAYANAN POS PENDIDIKAN ANAK USIA DINI DALAM PENINGKATAN AKSES PENDIDIKAN ANAK USIA DINI
}

\author{
THE ROLE OF EARLY CHILDHOOD EDUCATION POST IN IMPROVING ACCESS TO \\ EARLY CHILDHOOD EDUCATION
}

\author{
J.M. Tedjawati \\ Pusat Penelitian Kebijakan Pendidikan dan Kebudayaan, Balitbang Kemendikbud \\ email: tedjawatiks@gmail.com
}

Naskah diterima: 25/02/2016, direvisi akhir: 15/03/2016, disetujui: 03/04/2016

\begin{abstract}
Abstrak: Tujuan penelitian ini yaitu untuk mendeskripsikan dan menganalisis peran layanan PosPendidikan Anak Usia Dini (Pos-PAUD) dalam meningkatkan akses PAUD yang meliputi dukungan orangtua dan masyarakat, serta pelaksanaan layanan Pos-PAUD. Penelitian ini menggunakan pendekatan deskriptif kualitatif. Informasi layanan Pos-PAUD dikumpulkan dari empat kabupaten/kota pada tahun 2013. Hasil studi menemukan - pertama, semua orang tua menyadari pentingnya dan bermanfaatnya. Selain itu, dukungan masyarakat didasarkan pada penerimaan program PAUD dan ikut serta dalam sosialisasi pentingnya PAUD. Kedua, layanan Pos-PAUD dilaksanakan dengan adanya peserta didik di sekitar lembaga; pendidiknya dari kader Posyandu, pembinaan kesejahteraan keluarga, bina keluarga balita, yang relatif hanya lulusan Sekolah Menengah Atas dan bekerja dengan "sukarela" tanpa imbalan; sarana prasarana dan biaya masih terbatas dalam penyelenggaraannya. Tingkat capaian tumbuhkembang anak dipengaruhi oleh pemberian layanan dalam pendidikan dan kesehatan. Pendidikan dilaksanakan antara lain melalui penanaman nilai agama (berdoa), jalinan komunikasi dan kerjasama antar anak, sehingga anak lebih mandiri dan mengalami perubahan berpikir. Layanan kesehatan dilakukan dengan penimbangan berat dan tinggi badan, imunisasi dan pemberian makanan dengan gizi seimbang melalui pemberian sehingga diperoleh fisik yang sehat.
\end{abstract}

Kata Kunci: pendidikan anak usia dini, akses pendidikan, Pos Pendidikan Anak Usia Dini

\begin{abstract}
:
The purpose of this study is to describe and analyze the role of Early Childhood Education Post (ECD Post) in improving access to early childhood education including the parental and community support, as well as the implementation of ECD Post service. This study used a qualitative descriptive approach. Information about the ECD Post service was collected from four districts/cities in 2013. The study found, first, all parents were aware of the importance and benefits of early childhood education. In addition, public support was based on the acceptance of early childhood programs and participation in the importance of early childhood dissemination. Second, ECD Post service was conducted by the participation of learners living close to the institution; educators were from Posyandu, fostering family welfare, parenting education (Bina Keluarga Balita), who were relatively only high school graduates and working voluntarily without reward; the implementation was running on limited infrastructure and funding. The level of children's growth and development were affected by the provision of services in education and health. Education was carried out through the cultivation of religious values (praying) and also communication and cooperation among children in order to encourage children's independency and a better thought process. Health services were performed by weight and height control, immunization, and provision of balanced nutrition through various meal menu in order to obtain a healthy physique.
\end{abstract}

Keywords: early childhood education, access to education, Early Childhood Education Post 


\section{PENDAHULUAN}

Pendidikan yang paling mendasar bagi manusia adalah pendidikan sejak lahir sampai usia enam tahun. Pendidikan anak usia dini (PAUD) berperan meningkatkan semua potensi anak, dimana syaraf otak anak akan tumbuh dan berkembang jika mendapat stimulasi sesuai dengan pertumbuhan anak (Jalal, 2009). Stimulasi diperoleh melalui berbagai rangsangan yang diterima anak dari lingkungannya yaitu dari keluarga inti (ayah, ibu, kakak, adik), keluarga besar (kakek, nenek, saudara ayah dan ibu) dan masyarakat sekitarnya. Selain stimulasi dari keluarga dan masyarakat, stimulasi dapat diperoleh melalui pendidikan yaitu pada PAUD.

PAUD merupakan pendekatan yang diyakini mampu merangsang seluruh potensi kecerdasan yang dimiliki anak, dapat tumbuh dan berkembang secara optimal. Pendekatan PAUD yang digunakan dan sesuai dengan tumbuh dan kembang anak adalah bermain sambil belajar dan berlatih dalam suasana menyenangkan. Dengan demikian anak mampu menumbuhkembangkan imajinasi, kreativitas, keberanian, dan kemandiriannya. PAUD telah dicanangkan oleh Presiden Republik Indonesia pada tahun 2003. Program PAUD tersebut juga diperkuat dengan terbitnya UU nomor 20 tahun 2003 tentang Sistem Pendidikan Nasional, pasal 14 butir 14, yang menyatakan bahwa PAUD adalah suatu upaya pembinaan yang ditujukan kepada anak sejak lahir sampai dengan usia enam tahun yang dilakukan melalui pemberian rangsangan pendidikan untuk membantu pertumbuhan dan perkembangan jasmani dan rohani agar anak memiliki kesiapan dalam memasuki pendidikan lebih lanjut. Pada pasal 28 ayat 3 dan 4 dinyatakan bahwa pendidikan anak usia dini pada jalur pendidikan formal berbentuk Taman Kanak-kanak (TK) atau Raudatul Athfal (RA), dan jalur nonformal berbentuk Kelompok Bermain (KB), Taman Penitipan Anak (TPA), atau bentuk lain yang sederajat.

Dalam rangka mengembangkan potensi anak usia dini, pemerintah mengeluarkan Peraturan Presiden nomor 60 tahun 2013 tentang PAUD Holistik Integratif (PAUD HI) dan petunjuk teknis tentang penyelenggaraan PAUD HI di satuan PAUD (Kemdikbud, 2015). Peraturan tersebut merupakan komitmen pemerintah dalam menjamin terpenuhinya hak tumbuh kembang anak usia dini dalam hal pendidikan, kesehatan, gizi, perawatan, pengasuhan, serta perlindungan dan kesejahteraan anak. PAUD HI dilaksanakan secara simultan, sistematis, menyeluruh, terintegrasi dan berkesinambungan untuk mendukung tumbuh kembang yang optimal demi mewujudkan anak yang sehat, cerdas, dan berkarakter sebagai generasi masa depan yang berkualitas dan kompetitif. Selanjutnya, pemerintah juga mengeluarkan standar PAUD yang dapat digunakan sebagai acuan program PAUD (Kemdikbud, 2015). Standar PAUD bertujuan menjamin mutu PAUD, melalui pemberian stimulan pendidikan, pemberian 
perkembangan anak secara holistik dan integratif, serta persiapan pembentukan sikap, pengetahuan, dan keterampilan anak.

Pada saat ini, program peningkatan layanan PAUD yang sedang digalakkan sebagai dukungan untuk memperluas akses layanan PAUD adalah program "satu desa satu PAUD". Melalui program ini diharapkan pada tiap desa setidaknya terdapat satu lembaga PAUD. Jumlah desa di seluruh Indonsesia ada 80.858 dan desa yang telah memiliki lembaga PAUD sebanyak 57.727 atau 71,39 persen (Dapodik, 2013). Salah satu bentuk lembaga PAUD yang didirikan di desa adalah Pos-PAUD. Karena dalam pelaksanaannya Pos-PAUD dapat diintegrasikan dengan layanan Pos Pelayanan Terpadu (Posyandu) dan Bina Keluarga Balita (BKB) (Kemendikbud, 2013). Pada umumnya Pos-PAUD ini didirikan oleh masyarakat termasuk kepala desa dengan bekerja sama dengan kader yang ada di desa seperti kader Posyandu (kesehatan) dan kader BKB. PosPAUD ini diperuntukkan bagi masyarakat yang belum siap mengikutsertakan anaknya dalam layanan PAUD yang lebih intensif, baik karena alasan kerepotan mengantar, ekonomi, maupun masih rendahnya kesadaran orangtuanya. PosPAUD ini memberikan layanan rangsangan pendidikan bagi anak usia dini dan orangtuanya melalui pemberian wahana bermain dan contoh-contohnya.

Permasalahan pokok dalam penelitian ini yaitu bagaimana layanan Pos-PAUD - dalam peningkatan perluasaan akses PAUD ditinjau dari: i) dukungan orangtua dan masyarakat dalam penyelenggaraan layanan Pos-PAUD; ii) pelaksanaan layanan Pos-PAUD dan faktor yang berpengaruh terhadap tingkat capaian tumbuhkembang anak. Koheren dengan permasalahan tersebut, tujuan dari penelitian ini ialah untuk mendeskripsikan dan menganalisis program Pos-PAUD dalam meningkatkan akses PAUD meliputi dukungan orangtua dan masyarakat, serta pelaksanaan layanan Pos-PAUD.

\section{KAJIAN PUSTAKA \\ Pengertian PAUD}

Pertumbuhan dan perkembangan anak sejak dalam rahim sampai usia 6 tahun sangat menentukan derajat kesehatan, intelegensia, kematangan emosional dan spiritual, serta produktivitas manusia di masa berikutnya. Pada periode dua tahun pertama kehidupan, anak mulai mengendalikan emosi dan kebiasaan untuk bereaksi terhadap pengalaman baru dan memperoleh kemampuan berbahasa (Jalal, 2009: 27-28). Sedangkan kemampuan kognitif mulai berkembang pada tahun kedua terutama kemampuan untuk mengenal dan menggunakan simbol-simbol. Kemampuan ini merupakan prasyarat yang harus dimiliki anak untuk mulai belajar mambaca, menulis, dan berhitung yang terkait dengan angka. Pada anak usia tiga tahun bersamaan dengan kemampuan-kemampuan tersebut, berkembang pula kemampuan anak untuk bersosialisasi dengan teman sebayanya, dan 
berkembang terus sampai anak usia enam tahun. Sedangkan pada usia empat tahun, anak mampu memahami konsep kuantitas seperti membandingkan besaran atau volume. Setelah itu kemampuan kognitifnya berkembang dengan pesat. Semua kemampuan tersebut merupakan kemampuan dasar yang sangat penting dan harus dikuasai anak untuk kehidupan selanjutnya.

Dalam studi tentang pengembangan anak usia dini di Indonesia, Bappenas (2012) menemukan bahwa tujuan paling utama program PAUD adalah untuk meningkatkan kapasitas anak dalam berkembang dan belajar. Seorang anak yang sudah siap sekolah memiliki kombinasi karakteristik yang positif, yaitu sehat baik secara sosial dan emosional, percaya diri, dan ramah, memiliki hubungan pertemanan yang baik, menangani tugas-tugas yang menantang dan pantang menyerah; memiliki kemampuan berbahasa dan komunikasi yang baik; dan mendengarkan instruksi dengan baik dan penuh perhatian. Efek positif dari program PAUD dapat mengubah arah perkembangan anak saat mereka masuk sekolah.

Temuan Bappenas didukung hasil penelitian Universitas Atmajaya (2010) bahwa anak yang mengikuti program pengembangan anak di usia dini (PAUD) dapat mengembangkan kompetensi psiko sosial dan kognitif yang bermanfaat untuk kesiapan sekolah. Kompetensi tersebut meliputi: i) pra membaca; ii) pra menulis; iii) pra matematika; iv) berbahasa; dan v) memecahkan masalah. Selain itu, hasil penelitian tersebut juga menunjukkan bahwa anak lebih terampil dan luwes dalam menggunakan gunting dan pensil, mudah konsentrasi, dapat memahami instrusksi agak panjang dengan menggunakan bahasa Indonesia, dapat menyelesaikan tugas yang diberikan dengan baik dan tepat waktu, dan anak lebih mandiri.

Sejalan dengan itu, Unicef (2012) dalam penelitiannya tentang studi kesiapan bersekolah di enam kabupaten di Indonesia menunjukkan bahwa program PAUD telah membantu mengembangkan kompetensi psikososial dan kognitif untuk mempersiapkan anak-anak bersekolah, dengan melibatkan anak-anak dalam program-program tersebut minimal satu setengah tahun.

\section{Pos-PAUD}

Pelayanan berbasis masyarakat seperti Posyandu difokuskan terutama pada kesehatan dan gizi, dan BKB, program berbasis masyarakat lainnya, difokuskan pada pendidikan orangtua bagi para ibu dari anakanak muda, yang dipusatkan pada Pos-PAUD (Unicef, 2012). Oleh karenanya Pos-PAUD merupakan bentuk layanan PAUD yang penyelenggaraannya diintegrasikan dengan layanan BKB dan Posyandu bagi anak sejak lahir sampai dengan usia empat tahun dan dapat melayani anak hingga enam tahun jika di lokasi yang sama belum tersedia layanan TK/RA/KB, 
yang pengelolaannya di bawah pembinaan pemerintah desa/kelurahan. Sedangkan Posyandu merupakan pusat kegiatan masyarakat dimana masyarakat dapat sekaligus memperoleh layanan keluarga berencana, kesehatan ibu dan anak, gizi, imunisasi, dan penanggulangan diare. $\mathrm{BKB}$ adalah pembinaan yang ditujukan kepada orangtua dan anggota keluarga lainnya yang mempunyai anak balita tentang bagaimana membina tumbuh kembang anak balita secara terarah.

Kegiatan Pos-PAUD adalah PAUD HI. Holistik artinya bukan hanya stimulasi/rangsangan terhadap aspek pendidikan yang diberikan kepada anak usia dini, tetapi juga terhadap aspek gizi dan kesehatannya agar anak dapat tumbuh dan berkembangan secara optimal. Terintegrasi artinya bahwa layanan pendidikan dilaksanakan secara terpadu dengan berbagai layanan anak usia dini yang telah ada di masyarakat (seperti Posyandu, BKB, dan berbagai layanan anak usia dini lainnya). Pengembangan PAUD Holistik Integratif ini didukung melalui Peraturan Presiden nomor 60 tahun 2013 yang mengamanatkan bahwa program pengembangan anak usia dini hendaknya dilakukan secara holistik integratif.

Berdasarkan temuan yang dilakukan oleh Bappenas (2014), Posyandu yang menyatu dengan Pos-PAUD merupakan sarana utama bagi ibu dan anak-anak dari lahir sampai usia 2 tahun yang tidak akan dapat mengakses dukungan pelayanan lain selain pelayanan posyandu ini. Walaupun cakupan imunisasi lengkap di Indonesia baru mencapai 59 persen, namun anak-anak melalui Posyandu sudah mendapatkan imunisasi, dan perbaikan gizi. Selain itu, ditemukan pula bahwa: (i) lebih dari 90 persen anak usia 0-3 tahun memiliki akses ke Posyandu aktif di desanya; dan (ii) lembaga PAUD yang berintegrasi dengan Posyandu lebih berkelanjutan karena masyarakat merasa memiliki dan berkomitmen untuk pengembangan PAUD.

\begin{abstract}
Akses PAUD
Akses pendidikan adalah pemerataan kesempatan untuk memperoleh pendidikan. Akses terhadap pendidikan yang merata berarti semua penduduk usia sekolah telah memperoleh kesempatan pendidikan, sementara itu akses terhadap pendidikan telah adil jika antar kelompok bisa menikmati pendidikan secara sama.
\end{abstract}

Akses anak usia dini terhadap layanan pendidikan dan perawatan melalui PAUD masih terbatas dan tidak merata. Menurut data pokok pendidikan (dapodik) PAUD tahun 2013 jumlah peserta didik PAUD dari usia 0 sampai 6 tahun sebanyak 4.829.553 anak. Proyeksi Biro Pusat Statistik dan Badan Perencanaan Pembangunan Nasional tentang jumlah anak usia 0 sampai 4 tahun, pada tahun 2013 sebanyak 23.994.200 anak. Jika dibanding antara hasil proyeksi tersebut terhadap jumlah anak usia dini yang telah mengikuti PAUD 
maka terjadi masih banyak anak usia dini yang belum mengikuti PAUD.

Berkaitan dengan layanan Pos-PAUD, hasil penelitian Nuryana (2011) menunjukkan bahwa anak usia dini setelah mengikuti kegiatan pembinaan di Pos-PAUD pertumbuhan dan perkembangannya jadi meningkat. Temuan ini tentunya dapat mendukung keberadaan dan keberlangsungan Pos-PAUD dalam meningkatkan akses PAUD.

\section{KERANGKA BERPIKIR}

Fokus penelitian ini ialah ingin menjawab permasalahan terkait dengan akses PAUD, yakni bagaimanakah memperoleh layanan penyelenggaraan Pos-PAUD yang sesuai dengan tujuannya yaitu menjangkau masyarakat luas, memberi wahana bermain yang mendidik bagi anak, memberikan contoh kepada orangtua. Oleh karenanya ada dua faktor yang ditinjau dari penelitian ini yaitu dukungan penyelenggaraan Pos-PAUD dan pelaksanaan layanan Pos-PAUD. Faktor pertama, dukungan penyelenggaraan PosPAUD sangat penting karena Pos-PAUD adalah lembaga PAUD yang berasal dari, oleh, dan untuk masyarakat. Oleh karenanya dukungan Pos-PAUD dalam penelitian ini terdiri dari karakteristik orangtua, lingkungan tempat tinggal peserta didik, dan faktor yang berpengaruh pada partisipasi anak. Untuk karakteristik orangtua dan lingkungan tempat tinggal peserta didik terdiri dari latar belakang pendidikan, ekonomi, dan kesadaran akan program PAUD. Sedangkan faktor yang berpengaruh pada partisipasi meliputi jarak tempat tinggal anak, transportasi, dan angka partisipasi anak dalam program PAUD.

Faktor kedua, pelaksanaan layanan Pos-PAUD artinya bagaimana layanan Pos-PAUD dilaksanakan dalam meningkatkan program PAUD. Pelaksanaan layanan Pos-PAUD meliputi karakteristik peserta didik, karakteristik sumber daya (kualifikasi pendidik/pendamping, sarana prasarana, dan biaya PAUD), dan capaian tumbuhkembang anak dan faktor yang mempengaruhi. Semua data tersebut dianalaisis dan dijadikan dasar dalam peningkatan akses PAUD. 


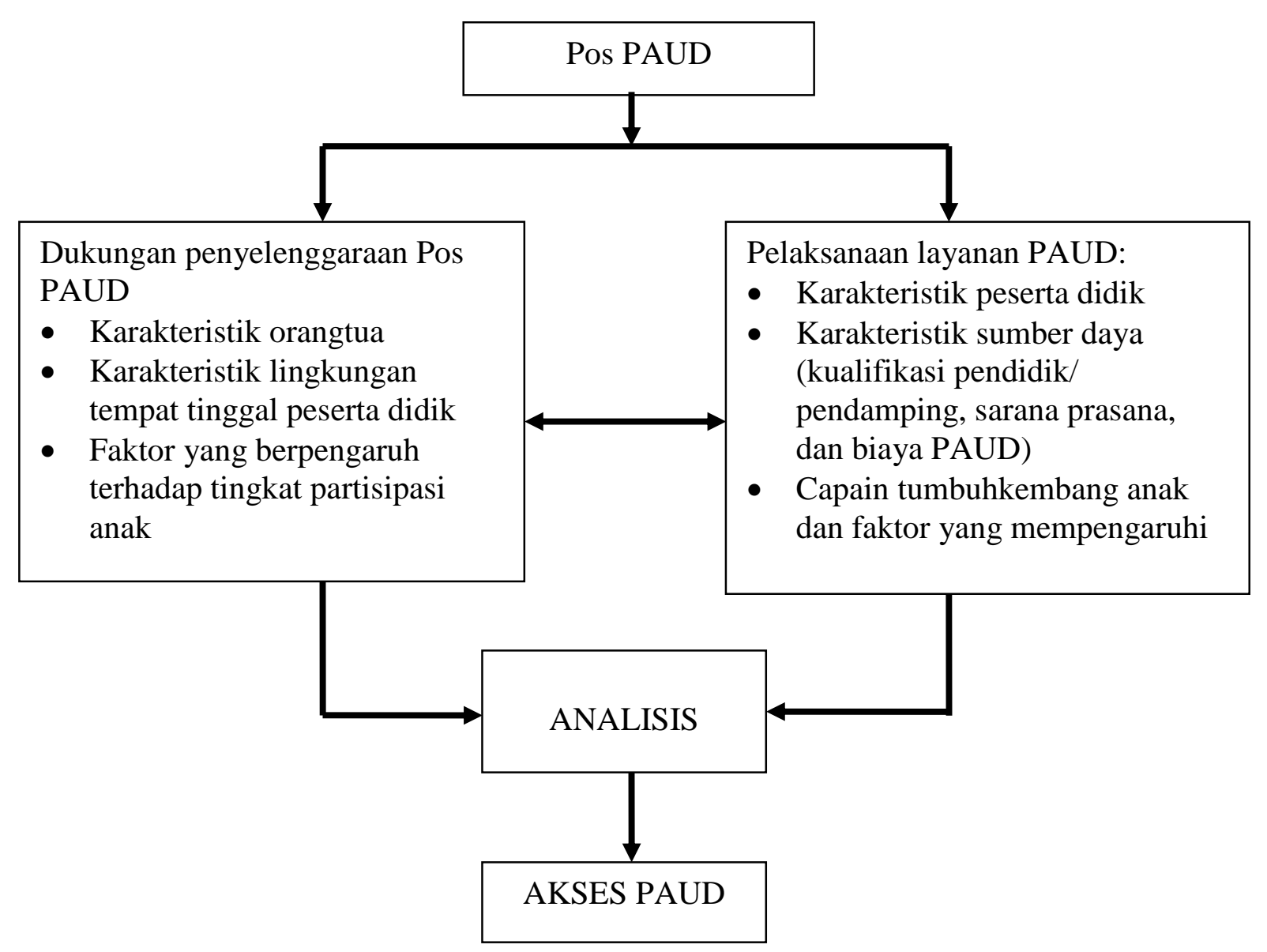

Gambar 1. Kerangka Pikir Studi

\section{Metode Penelitian}

Penelitian ini mengunakan pendekatan deskriptif kualitatif. Pendekatan kualitatif digunakan untuk mengidentifikasi, memahami, menggambarkan, dan menginterpretasikan informasi secara komprehensif tentang penyelenggaraan PosPAUD dan pelaksanaannya dalam rangka meningkatkan akses PAUD. Penyelenggaraan Pos-PAUD yang digali dalam penelitian ini meliputi karakteristik orangtua dan lingkungan tempat tinggalnya, faktor yang berpengaruh terhadap tingkat partisipasi anak, karakteristik peserta didik, karakteristik sumber daya (kualifikasi pendidik dan pendamping/pengasuh, sarana prasarana, dan biaya PAUD) dan capaian tumbuhkembang anak serta faktor yang mempengaruhi capaian tumbuhkembang anak tersebut.

Penelitian ini dilakukan tahun 2013 pada PosPAUD di empat kabupaten/kota, yaitu Kabupaten Belitung Timur, Kota Jayapura, Kabupaten Tasikmalaya, dan Kabupaten Ketapang. Kabupaten/kota tersebut dipilih dengan mempertimbangkan kepedulian pemerintahan daerah terhadap penyelenggaraan dan perkembangan PAUD. 
Pada masing-masing kabupaten/kota dipilih tiga Pos-PAUD dengan kriteria diselenggarakan dengan baik ditinjau dari dukungan orangtua/masyarakat, kepemilikan sumber daya, dan capaian tumbuhkembang anak.Pengumpulan data dalam penelitian dilakukan dengan wawancara secara mendalam, pengamatan/observasi, dan pengisian kuesioner. Pengisian kuesioner diberikan kepada pengelola dan pendidik PAUD serta dinas pendidikan kabupaten/kota. Pengamatan dilakukan di lembaga PAUD. Sedangkan wawancara mendalam dilakukan kepada pengelola dan pendidik PAUD. Analisis data dalam penelitian ini dilakukan setelah semua data diverifikasi dan kemudian diolah. Analisis data didukung dengan data hasil wawancara dan observasi.

\section{HASIL STUDI DAN PEMBAHASAN}

Peran Pos-PAUD dalam meningkatkan akses PAUD yang dibahas dalam tulisan ini mencakup dukungan penyelenggaraan PosPAUD dan pelaksanaan layanan PAUD. Dukungan penyelenggaraan mencakup karakteristik orangtua dan lingkungan tempat tinggalnya serta faktor yang berpengaruh terhadap tingkat partisipasi anak. Pelaksanaan layanan Pos-PAUD mencakup karakteristik peserta didik, karakteristik sumber daya, serta capaian tumbuhkembang anak dan faktor yang mempengaruhi capaian tumbuhkembang anak tersebut. Karakteristik sumber daya mencakup kualifikasi pendidik dan pendamping/pengasuh, sarana prasarana, dan biaya PAUD.

\section{Karakteristik orangtua peserta didik dan lingkungan tempat tinggal}

Pendidikan orangtua beragam, 61,1 persen lulusan SMA dan 38,9 persen di bawah SMA. Walau hanya lulusan SMA atau di bawahnya, namun semua orangtua sudah menyadari untuk memberikan pendidikan kepada anak sedini mungkin dan mengantarkan anaknya siap mengikuti pendidikan lebih lanjut dan siap memasuki lingkungan lebih luas. Pendapat tersebut diperoleh dari pengelola PAUD melalui pengamatan dan dialog yang dilakukan kepada orangtua. Temuan ini diperkuat hasil studi Bappenas (2014) bahwa orangtua mulai sadar akan pentingnya dan bermanfaatnya PAUD bagi anak-anak. Walau kesadaran tersebut menganggap PAUD sebagai program yang lebih dianggap sebagai penyiapan baca-tulis-hitung daripada pengembangan anak secara holistik, terlepas dari kenyataan bahwa PAUD seharusnya berfokus pada penumbuhkembangan yang lebih mendasar agar dapat berhasil di sekolah.

Selanjutnya, temuan di lapangan menunjukkan bahwa pos-PAUD mengharapkan orangtua dapat melaksanakan penumbuhkembangan anak di rumah sesuai dengan yang dilakukan di pos-PAUD. Dengan demikian tumbuhkembang anak di pos-PAUD dan di rumah berkesinambungan sehingga capaian 
anak yang meliputi berbagai aspek yakni: agama, moral, fisik, kognitif, bahasa, dan sosial sesuai dengan perkembangan dan kemampuan anak. Komunikasi antara orangtua dan lembaga PAUD sangat menentukan dalam pendidikan anak. Orangtua yang menunggu anaknya di sekolah mendapatkan penyuluhan mengenai anak usia dini yang dilakukan oleh pengelola PAUD, seperti pengetahuan antara kesehatan dengan perkembangan anak dengan kesiapan untuk masuk ke jenjang sekolah dasar (Bappenas: 2014). Selain itu, di rumah orangtua membantu anaknya untuk mengulang materi penumbuhkembangan yang diterima di posPAUD seperti menghafalkan lagu, memperkenalkan angka dan huruf.

Selanjutnya, pembelajaran anak usia dini harus dikaitkan dengan unsur lokal seperti budaya lokal, permainan, lagu atau tarian tradisional. Pada saat ini banyak pendidik tidak mengenal lagi atau sudah lupa terhadap pengetahuan tradisional, bahkan dalam hal yang sederhana seperti permainan anak, lagu, alat musik, masakan, dan bahasa tradisional (http://widyariset.pusbindiklat.lipi.go.id/index .php/widyariset/article/viewFile/140/134).

Selain itu, manfaat yang diperoleh dari menu pembelajaran anak usia dini bermuatan lokal, antara lain menumbuhkan rasa percaya diri anak, kebanggan pada karya sendiri, mengembangkan kreativitas, memecahkan masalah, keterampilan berbahasa, serta kemampuan sopan santun berinteraksi dengan orang lain dalam kerangka budaya lokal.

Hasil temuan lain di lapangan menunjukkan bahwa alasan orangtua menyekolahkan anaknya ke Pos-PAUD antara lain karena rumah tempat tinggal orangtua dekat dengan tempat penyelenggaraan, mutu pos-PAUD baik, biaya yang terjangkau oleh para orangtua, serta tidak ada PAUD lain di sekitar tempat tinggal. Berikut temuan alasan orangtua di daerah sampel yang menyekolahkan anaknya di Pos-PAUD. Alasan pertama adalah metode pembelajaran mudah dipahami dan dipraktekkan (pendapat di Kabupaten Tasikmalaya). Alasan kedua adalah pendidiknya telah mengikuti pelatihan (pendapat di Kabupaten Tasikmalaya). Alasan ketiga adalah adanya program khusus untuk pembinaan mental spiritual dan budi pekerti (pendapat di Kota Jayapura), dan alasan keempat adalah biaya yang murah dan masih terjangkau, bahkan gratis (pendapat di Kabupaten Ketapang) dan uang infaq hanya Rp 10.000,- per bulan (pendapat di Kota Jayapura). Temuan tersebut didukung pula dengan hasil penelitian yang dilakukan oleh Suprihati (2012: 4) bahwa keberadaan PosPAUD di lingkungan kelurahan menjadikan warga yang tergolong keluarga pra-sejahtera tidak perlu mengeluarkan biaya pendidikan yang mahal untuk anak mereka dan dapat berperan aktif dalam proses pembelajaran yang dilaksanakan di Pos-PAUD. 
Berdasarkan data isian yang diberikan kepada orangtua, ditemukan bahwa status ekonomi orangtua umumnya tergolong lemah. Penghasilan orangtua peserta didik di lembaga Pos-PAUD sangat beragam. 57,1 persen berpenghasilan antara Rp 1.000.000,- sampai dengan Rp 2.500.000,- per bulan, dan 37,1 persen orangtua berpenghasilan di bawah $\mathrm{Rp}$ 1.000.000,- per bulan. Temuan tersebut menunjukkan bahwa dengan penghasilan yang rendah, tidak mengurangi semangat orangtua untuk menyekolahkan anaknya.

\section{Karakteristik masyarakat lingkungan tempat Pos-PAUD}

Dukungan masyarakat di sekitar tempat penyelenggaraan Pos-PAUD sangat memengaruhi keberlangsungan pos-PAUD. Pengelola menyatakan bahwa pendidikan masyarakat sekitar Pos-PAUD juga sangar beragam dan cenderung tidak tinggi. 66,7 persen orangtua lulus SMA, sedangkan selebihnya lulusan di bawah SMA (tidak ada yang lulusan pendidikan tinggi). Walaupun pendidikan masyarakat tergolong rendah, tidak menyurutkan dukungan masyarakat terhadap penyelenggaran lembaga PAUD di sekitarnya. Dukungan tersebut didasarkan adanya penerimaan secara positif dan dukungan lain pada saat sosialisasi pentingnya PAUD yang diberikan oleh pengelola PosPAUD. Sosialisasi program PAUD di lakukan pengelola tersebut dalam bentuk: i) pamflet dan spanduk (Kabupaten Tasikmalaya); ii) pengajian (Kabupaten Tasikmalaya); iii) kegiatan parenting (Kota Jayapura, Kabupaten Belitung Timur); iv) sosialisasi dari rumah ke rumah masyarakat (Kabupaten Belitung Timur); v) kegiatan posyandu (Kabupaten Belitung Timur).

Dari sisi lain, pengelola PAUD juga mengungkapkan bahwa pada umumnya masyarakat di lokasi penelitian berpenghasilan rendah. 52,8 persen pengelola menyatakan bahwa penghasilan masyarakat antara $\mathrm{Rp}$ 1.000.000,- sampai dengan Rp 2.500.000,-. 25 persen pengelola menyatakan bahwa orangtua ada yang berpenghasilan kurang dari $\mathrm{Rp}$ 1.000.000,-, dan 5,6 persen pengelola menyatakan orangtua berpenghasilan di atas Rp 2.500.000,- per bulan. Walau kondisi penghasilan masyarakat tersebut relatif rendah, namun mereka menunjukkan antusiasme yang positip terhadap penyelenggaraan PAUD ini. Temuan ini didukung dengan pandangan masyarakat Kabupaten Sambas (Bappenas, 2013) bahwa anak yang mengikuti PAUD menjadi lebih mandiri, bersosialisasi, mampu berinteraksi dengan prang lain dengan sopan, sehat dan perilaku bersih meningkat dan anak-anak dapat mengenal huruf, angka, bentuk, warna, dan berdoa.

Dukungan masyarakat sangat penting dalam penyelenggaraan Pos-PAUD. Sejalan dengan itu, Kurniawati (2011) menemukan bahwa keberlangsungan Pos-PAUD sangat tergantung pada keberadaan pengelola yang 
mampu secara berkesinambungan serta dukungan masyarakat kepada Pos-PAUD.

\section{Faktor yang terkait terhadap tingkat partisipasi anak}

Beberapa faktor yang cenderung mempengaruhi tingkat partisipasi anak, antara lain adalah rerata jarak dari tempat tinggal anak menuju ke lembaga Pos-PAUD, transportasi yang digunakan menuju lembaga PAUD, pendididikan dan penghasilan orangtua anak, dan upaya lembaga PAUD dalam melakukan sosialisasi untuk meningkatkan APK. Temuan di lapangan menunjukkan bahwa rata-rata jarak dari tempat tinggal anak menuju ke lembaga PosPAUD relatif dekat, yakni hanya 294 meter. Jarak ini ditempuh dengan berjalan kaki dilakukan oleh 75 persen orangtua, dan naik kendaraan motor dilakukan oleh orangtua lainnya. Selanjutnya ditinjau dari kondisi orangtua anak, ditemukan bahwa pendidikan semua orangtua anak di POS-PAUD rendah, hanya lulusan SMA atau SMP. Hal ini juga sesuai dengan kondisi ekonomi orangtua anak, semua orangtua hanya berpenghasilan di bawah Rp 2.500.000,-.

Dari hasil data dan diskusi dengan dinas pendidikan kabupaten/kota di empat kabupaten/kota sampel, diperoleh rerata besaran angka partisipasi kasar PAUD 51,75 persen. Angka ini masih jauh dari target pemerintah pada akhir tahun 2015 sebesar 75 persen; kendati pemerintah daerah telah melakukan intervensi untuk meningkatkan APM tersebut. Upaya telah dilakukan oleh dinas pendidikan dan mitra PAUD untuk meningkatkan akses pos-PAUD yaitu melakukan sosialisasi pentingnya PAUD melalui pertemuan pada kegiatan Posyandu, PKK, dan Himpaudi; siaran radio (di Kabupaten Tasikmalaya); dan kegiatan lomba bagi anak usia dini.

\section{Karakteristik peserta didik}

Anak-anak PAUD umumnya berasal dari keluarga dengan berbagai latar belakang sosial, ekonomi dan budaya, serta agama. PosPAUD sejak awal menerima anak tanpa membedakan latar belakang agama, suku bangsa, asal daerah, dan status sosial ekonomi. Alasan tidak membedakan latar belakang tersebut antara lain adalah: pendidikan merupakan hak setiap anak (pendapat di Kabupaten Belitung Timur dan Kabupaten Ketapang); dan anak didik dapat menjalin persatuan dan kesatuan (pendapat di Kabupaten Ketapang).

Pos-PAUD memiliki rerata peserta didik sebanyak 45 anak, mulai dari usia 0 sampai $\leq$ 7 tahun. Jumlah ini dirasa masih rendah jika dibandingkan dengan jumlah peserta didik di lembaga lain seperti TK, yang memiliki peserta didik lebih dari 100 anak mulai usia 3 sampai $\leq 7$ tahun (Puslitjak, 2013). Hal ini disebabkan lembaga Pos-PAUD baru berdiri sejak tahun 2005 sedangkan keberadaan TK sudah diketahui masyarakat sejak tahun 1950 . 
Pada saat ini pengelola Pos-PAUD belum menerima anak berkebutuhan khusus. Ini desebabkan antara lain karena tidak adanya pendidik yang khusus menangani anak tersebut (Kabupaten Tasikmalaya dan Kota Jayapura); di lingkungan lembaga tidak ada anak berkebutuhan khusus (Kabupaten Tasikmalaya dan Kota Jayapura).

\section{Karakteristik pendidik Pos-PAUD}

Berdasarkan isian kuesioner penyelenggara pos-PAUD ditemukan bahwa kualifikasi pendidikan dari pendidik di Pos-PAUD cenderung pendidikan rendah. Hanya 16,47 persen yang berpendidikan S1 dan 56,65 persen berpendidikan lulusan SMA. Temuan ini menunjukkan bahwa kualifikasi yang dimiliki pendidik lembaga PAUD tersebut belum mencapai standar Kualifikasi Akademik dan Kompetensi Guru yaitu pendidik PAUD minimal berpendidikan jenjang S1. Temuan tersebut sejalan dengan temuan dari penelitian Bappenas (2013) yang menunjukkan bahwa tutor di daerah yang berdedikasi tinggi dan menunjukkan kinerja baik tidak selalu bergelar akademik tinggi karena beberapa tutor di daerah hanya memiliki ijasah SD. Untuk itu kepribadian dan komitmen merupakan faktor yang lebih penting dibandingkan dengan kualifikasi formal. Selain itu, adanya kebijakan pemerintah bahwa guru termasuk pendidik PAUD, diharuskan pada tahun 2015 sudah berpendidikan S1. Apabila guru PAUD berpendidikan sekolah menengah ini harus menyelesaikan program sarjananya maka mereka setidaknya harus mengikuti pendidikan selama empat tahun untuk menyelesaikan program S1.

Selanjutnya, kualifikasi pendamping/ pengasuh di lembaga Pos-PAUD mayoritas berpendidikan lulusan SMA. Kualifikasi pendidikan dari para pendamping/pengasuh ini sesuai dengan standar PAUD yaitu minimal lulusan SMA. Pendidik dan pendamping/pengasuh di Pos-PAUD sebagian besar merupakan kader Posyandu dan PKK. Namun, rendahnya kualifikasi pendidikan dari pendidik dan pendamping tersebut, seharusnya diimbangi dengan pelatihan tentang PAUD. Pentingya pemberian pelatihan program PAUD HI bagi pendidik Pos-PAUD dapat meningkatkan kualitas Pos-PAUD. Para pendidik Pos-PAUD belum mengetahui bagaimana pelayanan yang utuh dan terpadu (Handayani, dkk, 2011). Pelatihan tersebut meliputi pemberian stimulasi atau rangsangan sejak usia dini sangat penting untuk melejitkan semua aspek perkembangan anak, cara membuat makanan sehat untuk anak usia dini dan cara menjaga kesehatan anak, dan pengetahuan tentang parenting. Temuan tersebut didukung hasil penelitian Nuryana (2011) bahwa kader Pos-PAUD dalam menjalankan tugasnya untuk memberikan penyuluhan kepada para orangtua, memotivasi, memberikan solusi terhadap permasalahan tumbuh kembang anak yang 
dihadapi oleh orangtua dan mengadakan kunjungan rumah.

Dari hasil wawancara dengan pendidik, ditemukan bahwa pendidik dan pengasuh PosPAUD tidak menerima insentif secara rutin. Karena keterbatasan kemampuan orangtua untuk membayar iuran dan kadang ada orangtua yang "gratis", maka sebagian besar pendidik Pos-PAUD tidak menerima imbalan dan mereka ini bekerja dengan "sukarela" karena dedikasinya untuk mengasuh dan mendidik anak usia dini. Namun ada juga lembaga Pos-PAUD yang memberikan insentif bagi pendidiknya walau dengan jumlah relatif kecil, yaitu sekitar Rp 100.000,per bulan. Pemerintah daerah dari sampel belum dapat memberikan bantuan insentif bagi pendidik Pos-PAUD, dengan alasan keterbatasan dana pemerintah daerah untuk pendidikan.

\section{Sarana prasarana}

Berdasarkan hasil penelitian, ditemukan bahwa lembaga Pos-PAUD telah memenuhi persyaratan minimal prasarana yang harus dimilikinya. Umumnya PAUD telah memiliki ruangan dalam, halaman untuk bermain, serta sanitasi dan WC yang bersih. Persyaratan tersebut dipenuhi walau luas ruangan dan halaman kurang memadai untuk belajar sambil bermain.

Terdapat tiga jenis peralatan yang telah dipenuhi oleh Pos-PAUD yaitu gambar dan karya anak, lemari atau rak untuk wadah alat bermain, papan tulis (white atau black board), serta alat tulisnya (Tabel 1). Kenyataan bahwa cermin belum dimiliki oleh semua lembaga Pos-PAUD. Ini menunjukkan bahwa belum semua lembaga Pos-PAUD mengetahui fungsi dari keberadaan cermin yaitu anak dapat mengaca dan bergaya di depan cermin sehingga anak dapat mengetahui gerak tubuhnya (psikomotorik) dan bagian tubuhnya seperti mata, kaki, tangan, dan sebagainya.

Tabel 1. Presentase Jenis Peralatan Yang Ada Dalam Ruang Bermain

\begin{tabular}{|c|l|c|}
\hline No. & \multicolumn{1}{|c|}{ Jenis Peralatan dalam Ruang Bermain } & Presentase (persen) \\
\hline 1 & Jam dinding & 37,5 \\
\hline 2 & Cermin & 33,3 \\
\hline 3 & VCD Player & 20,0 \\
\hline 4 & Lemari atau rak untuk wadah alat main & 57,1 \\
\hline 5 & Gambar dan karya anak & 62,5 \\
\hline 6 & AC atau Kipan Angin & 25,0 \\
\hline 7 & Papan tulis (white atau black board) serta alat tulisnya & 53,1 \\
\hline 8 & Papan flannel dan perlengkapannya & 25,0 \\
\hline & Rerata & 39,1 \\
\hline
\end{tabular}


Ditinjau dari jenis sentra yang dimilik lembaga Pos-PAUD, nampak bahwa Sentra imtaq telah dimiliki oleh semua lembaga Pos-PAUD. Sedangkan sentra lainnya sentra balok, sentra main peran, sentra seni kreatif, sentra musik, dan sentra alam hanya dimiliki oleh sebagian lembaga Pos-PAUD. Tidak semua sentra tersebut ditempatkan di ruang tersendiri. Ada satu ruang dibagi dua atau tiga untuk beberapa jenis sentra. Seringkali sentra kegiatan disiapkan sesuai dengan tema kegiatan yang akan diikuti anak setiap harinya. Temuan tersebut menunjukkan bahwa karena keterbatasan pembiayaan dan prasarana yang dimiliki Pos-PAUD maka kegiatan yang menggunakan sentra dilakukan secara bergantian. Kecuali pada lembaga PAUD yang sudah "mapan" dan memiliki sumber biaya yang mencukupi, tentu akan menyiapkan satu ruang untuk kegiatan satu sentra.

Tabel 2. Presentase PAUD yang Memiliki Jenis Sentra/Sudut

\begin{tabular}{|c|l|c|}
\hline No. & \multicolumn{1}{|c|}{ Jenis sentra/sudut } & $\begin{array}{c}\text { Presentase } \\
\text { (persen) }\end{array}$ \\
\hline 1 & Sentra balok & 50,0 \\
\hline 2 & Sentra main peran & 50,0 \\
\hline 3 & Sentra IMTAQ & 100,0 \\
\hline 4 & Sentra seni kreatif & 50,0 \\
\hline 5 & Sentra musik & 37,5 \\
\hline 6 & Sentra alam & 50,0 \\
\hline 7 & Sentra persiapan masak & 0,0 \\
\hline
\end{tabular}

Pada Tabel 2 tampak bahwa sumber belajar yang dimiliki oleh sebagian Pos-PAUD yaitu buku cerita anak, poster tentang gambar bagi anak, dan buku sumbangan guru pasti berkaitan dengan pembelajaran dan permainan bagi anak. Temuan tersebut menunjukkan bahwa PosPAUD sudah berusaha menyediakan buku sebagai sumber belajar bagi anak, walau belum memenuhi semua sumber belajar yang menarik dan dibutuhkan anak usia dini.

Tabel 3. Presentase PAUD yang Memiliki Jenis sumber belajar

\begin{tabular}{|r|l|c|}
\hline No. & Jenis sumber belajar & $\begin{array}{c}\text { Persentase } \\
\text { (persen) }\end{array}$ \\
\hline 1 & Buku cerita & 25,0 \\
\hline 2 & Buku cerita anak & 50,0 \\
\hline 3 & Ensiklopedia & 20,0 \\
\hline 4 & Buku sumbangan guru & 50,0 \\
\hline 5 & Kamus & 20,0 \\
\hline 6 & Majalah anak & 20,0 \\
\hline 7 & Poster & 53,1 \\
\hline & Rerata & 34,0 \\
\hline
\end{tabular}

Dari analisis data diperoleh informasi bahwa hanya ada beberapa jenis APE yang dimiliki oleh sebagian besar Pos-PAUD yaitu balok, puzzle, crayon, pensil, bolpoin, kapur, dan lainnya, serta peralatan meronce. Permainan 
dengan balok dan permainan puzzle merupakan permainan konstruktif. Permainan balok sangat bermanfaat bagi anak, tidak hanya anak bisa menyusun beberapa balok untuk membangun jembatan, menara, jalan dan lainnya, tetapi anak belajar mengenai konsep (warna, bentuk, ukuran, dan keseimbangan), mengembangkan imajinasi, melatih kesabaran, secara sosial belajar berbagi, dan mengembangkan rasa percaya diri anak. Sedangkan permaianan puzzle memiliki manfaat cukup baik, sebab permainan ini terutama untuk anak usia 2 sampai 4 tahun sangat baik untuk mengasah kemampuan spasial anak yaitu kebiasaan untuk berpikir tentang obyek. Namun dari hasil penelitian yang dilakukan oleh Chasanatun (2016) bahwa APE yang digunakan dalam permainan tidak harus yang mahal tetapi alat yang mudah seperti sedotan dan karet, dengan tali, dan lainnya sehingga dapat menghibur dan membangkitkan minat anak. Intinya dalam permainan tersebut harus sesuai dengan kebutuhan tumbuh kembang anak dan memiliki nilai-nilai kebajikan, sehingga permainan yang diberikan tidak memberikan dampak negatif bagi anak tetapi dapat mendidik karakter anak.

Jenis APE luar yang dimiliki Pos-PAUD relatif hanya beberapa jenis seperti ayunan dan papan luncur. Mainan panjatan belum dimiliki oleh Pos-PAUD. Temuan tersebut menunjukkan bahwa lembaga Pos-PAUD belum menyediakan berbagai jenis APE luar yang lengkap disebabkan karena keterbatasan dana dan ruang atau halaman luar yang dimiliki PosPAUD.

\section{Capaian Tumbuhkembang Anak}

Capaian perkembangan anak merupakan salah satu faktor yang mengindikasikan mutu layanan Pos-PAUD. Pos-PAUD memiliki hasil capaian perkembangan anak sebesar 61 persen. Capaian ini diperoleh dari pendapat pendidik PAUD dan hasil ini merupakan rangkuman dari lima aspek perkembangan anak yaitu aspek agama dan moral, kognitif, psikomotorik, bahasa, dan sosial emosional. Dari hasil pengamatan pendidik ternyata Pos-PAUD telah menerapkan proses pembelajaran sesuai dengan standar PAUD. Dari sisi anak usia dini telah mengalami perubahan-perubahan dalam berpikir (kognitif), kemajuan gerak di tubuhnya (psikomotorik), bertambahnya kosa kata dan bicaranya semakin baik (bahasa), belajar mana yang baik dan tidak, cara berdoa kepada Tuhan (agama dan moral), dapat bekerjasama dengan anak sebaya (sosial), lebih mandiri, sesuai dengan Siklus kehidupan anak sejak dini.

Ada beberapa faktor yang mempengaruhi nilai capaian perkembangan anak di Pos-PAUD. Faktor-faktor tersebut adalah, (i) kepemilikan APE dalam; (ii) kepemilikan APE luar; (iii) sumber belajar masih kurang; (iv) peralatan dalam ruang belajar; (v) sumber belajar. Selain itu, penyelenggaraan Pos-PAUD dilakukan di tempat ruang yang terbatas, masih menyewa atau pinjam gedung di balai desa (jarang yang 
memiliki sendiri tempat pembelajaran), pembelajaran hanya berlangsung satu sampai tiga kali setiap minggunya, banyaknya orangtua peserta didik yang tidak mampu membiayai anak, sehingga biaya untuk operasional penyelenggaraan PAUD mengalami kekurangan dana. Hal ini tentu berdampak pada kurangnya dana dalam penyediaan APE dalam dan APE luar, alat dan sumber belajar bagi anak.

Jenis teknik penilaian tumbuhkembang anak meliputi pengamatan/observasi, pencatatan tingkah laku khusus yang ditunjukan anak dalam buku anekdot, dan pengumpulan hasil kerja anak (portofolio). Hasil analisis data menunjukkan bahwa hanya 30.56 persen Pos-PAUD yang menggunakan ketiga teknik tersebut. Walaupun demikian, penyelenggara Pos-PAUD menyampaikan laporan bagi orangtua sehingga tumbuh kembang anak dapat diketahui oleh orangtua. Dengan demikian kombinasi pengamatan/ observasi, pencatatan tingkah anak, pengumpulan hasil kerja anak, dan laporan untuk orangtua, dapat menjalin kerjasama antara pendidik/pengelola dengan orangtua sehingga terjadi kesinambungan dalam penanaman nilai agama/moral, cara berbicara dan bertingkah laku yang baik, menjalin kerjasama dengan teman sebaya, dan lainnya.

Selanjutnya, ditemukan bahwa kondisi kesehatan dan pengasuhan anak juga diperhatikan di Pos-PAUD. Artinya layanan Pos-PAUD dilaksanakan secara terpadu dengan berbagai layanan anak usia dini yang telah ada di masyarakat, seperti Posyandu, dan BKB. Oleh karenanya, pendidiknya berasal dari kader Posyandu, BKB, dan PKK. Mereka bertugas untuk melakukan penyuluhan kesehatan dan pengasuhan anak. Temuan ini didukung dengan penelitian dari Siswanto (2012: 315) bahwa pelayanan kesehatan yang diberikan kepada anak usia dini berupa pelayanan kesehatan dasar meliputi penimbangan berat dan tinggi badan, imunisasi dan pemberian zat gizi seimbang melalui pemberian makanan yang beraneka ragam merupakan pemberian pengalaman nyata, bagaimana membuat pertumbuhan fisik sehat dan dapat menunjang perkembangan psikososial sehingga menghasilkan suatu jiwa atau mental yang sehat. Selanjutnya, Siswanto mengatakan bahwa pendidikan kesehatan anak usia dini tidak hanya sebagai proses pembelajaran, tetapi juga dalam bentuk layanan kesehatan sebagai pengalaman nyata mengoptimalkan potensi pertumbuhan dan perkembangan sebagai unsur utama dalam PAUD.

\section{Pendanaan}

Terkait dengan pembiayaan pendidikan, ditemukan alokasi terbesar biaya yang dikeluarkan oleh lembaga Pos-PAUD adalah biaya gaji tenaga kependidikan (tendik), termasuk biaya transportasi dan biaya konsumsi. Hal ini disebabkan gaji tendik ditanggung oleh penyelenggara, karena hanya sebagian kecil pendidik yang mendapat insentif 
yang disediakan oleh pemerintah. Temuan ini memiliki korelasi dengan hasil penelitian yang dilakukan oleh Wijayanti (2012:143) bahwa pemerintah seharusnya menganggarkan dana pendidikan bagi Pos-PAUD Terpadu, dengan tujuan untuk meningkatkan kualitas PosPAUD dan bukan kepentingan politik.

Tabel 4. Biaya Penyelenggaraan Pos-PAUD

\begin{tabular}{|l|l|c|c|}
\hline No. & \multicolumn{1}{|c|}{ Jenis pembiayaan } & Kisaran jumlah biaya $(\mathrm{Rp})$ & Presentase (persen) \\
\hline 1. & Biaya gaji tendik & $1.440 .000-3.800 .000$ & 62,5 \\
\hline 2. & Biaya pengembangan tendik & $115.000-2.000 .000$ & 40,0 \\
\hline 3. & Biaya proses pembelajaran & $533.000-3.000 .000$ & 50,0 \\
\hline 4. & Biaya sarana prasarana & $1.500 .000-8.500 .000$ & 50,0 \\
\hline 5. & Biaya bahan habis pakai & $500.000-3.600 .000$ & 57,1 \\
\hline
\end{tabular}

\section{Simpulan dan Saran}

\section{Simpulan}

Atas dasar hasil penelitian dan pembahasan, dapat disimpulkan bahwa peran Pos-PAUD dalam meningkatkan akses PAUD. Pertama, partisipasi orangtua untuk memasukkan anaknya ke lembaga Pos-PAUD sangat mudah. Hal ini diindikasikan oleh jarak ke Pos-PAUD sangat dekat dan ditempuh dengan berjalan kaki. Walau pendidikan dan penghasilan orangtua rendah, namun adanya sosialisasi tentang pentingnya PAUD, menyadarkan orangtua mau memajukan pendidikan bagi anaknya dengan memasukkan ke Pos-PAUD. Kondisi ini juga mempengaruhi pembiayaan penyelenggaraan di Pos-PAUD karena penghasilan orangtua yang rendah dan masih banyak orangtua yang membayar dengan biaya rendah dan ada pula yang tidak membayar. Kedua, peserta didik di Pos-PAUD relatif cukup banyak karena mereka ikut kegiatan Posyandu. Pendidik dan pendamping di Pos-
PAUD juga merupakan kader Posyandu, PKK, dan BKB, yang sebagian besar hanya memiliki kualifikasi lulusan SMA dan kurang mengikuti pelatihan yang mendukung pengetahuan tentang tumbuhkembang anak. Pendidik dan pendamping ini bekerja dengan sukarela karena tidak cukupnya biaya untuk memberi imbalan/tunjangan bagi pendidik. Ketiga, capaian tumbuhkembang anak di Pos-PAUD menurut perkiraan pendidiknya mencapai nilai cukup. Anak mengalami perubahan cara berpikir, berkomunikasi dengan menggunakan bahasa yang baik, bekerjasama dengan teman sebaya, berdoa dengan baik, dan lebih mandiri. Disamping itu, kondisi kesehatan dan pengasuhan yang diterima anak lebih baik karena adanya kesinambungan materi yang diberikan oleh pendidik dengan orangtua. Partisipasi dan kesadaran orangtua dengan memasukkan anaknya ikut Pos-PAUD, sangat dihargai walau pendidikannya hanya SMA ke bawah dan penghasilan yang rendah. Keempat, 
koordinasi antara lembaga Pos-PAUD dengan orangtua dan instansi terkait seperti kesehatan, keluarga berencana, dan program pembinaan keluarga sangat menunjang keberlangsungan lembaga Pos-PAUD. Semakin besar orangtua sadar pentingnya pendidikan dan ikut memasukkan anaknya untuk ikut PAUD, maka angka partisipasi peserta didik di lembaga PAUD akan meningkat.

\section{Saran}

Pertama, dalam rangka memberikan layanan pendidikan yang lebih baik kepada anak usia dini disarankan agar lembaga Pos-PAUD yang mudah diakses oleh orangtua dan mengalami kekurangan fasilitas yang mendukung perkembangan anak, diberi pembinaan dan bantuan dari pemerintah daerah atau masyarakat setempat, terutama dari desa yang memiliki dana dan diperbolehkan untuk membantu dalam pembinaan PAUD. Hal ini sangat penting mengingat anak usia dini memiliki peran yang penting dalam pembangunan negara pada waktu yang akan datang. Oleh karenanya pemerintah dan masyarakat harus menjalin koordinasi dalam keberlangsungan lembaga PAUD agar anak usia dini dapat meningkatkan tumbuhkembangnya sesuai dengan psikologi anak.

Kedua, para pendidik di Pos-PAUD memiliki kualifikasi pendidikan rendah, sebagian besar hanya lulusan SMA. Para pendidik ini perlu diberikan pelatihan yang didahului dengan analisis kebutuhan. Dalam melaksanakan pelatihan ini dinas pendidikan dapat bekerjasama dengan Himpaudi dan IGTKI.

Ketiga, kurangnya fasilitas sarana dan prasarana yang dimiliki lembaga Pos-PAUD perlu diupayakan bantuan dari perusahaan (corporate social responsibility) yang dikoordinasi oleh dinas pendidikan setempat. Disamping itu bantuan yang diberikan pemerintah atau CSR tersebut perlu diprioritaskan pada lembaga Pos-PAUD yang baru berdiri dan kurang mampu, yang tidak mampu mencari dana sendiri karena kecenderungannya memang menampung anakanak dari keluarga dengan kemampuan ekonomi rendah. 


\section{DAFTAR PUSTAKA}

Arri Handayani, Muniroh Munawar, Anita Chandra D.S., dan Dwi Prasetiyawati D.H., 2011. Peningkatan Kualitas Pos-PAUD Melalui Pengembangan Program Holistik Integratif (Penelitian Tindakan Pada Pos-PAUD Se-Kelurahan Penggaron Kidul). Jurnal Penelitian PAUDIA, I (1), hlm. 75-90.

Atmajaya, Universitas dan UNICEF. 2010. Evaluasi Kesiapan Sekolah. Jakarta: Universitas Atmajaya.

Badan Perencanaan Pembangunan Nasional (Bappenas), 2012. Pedoman Umum Pengembangan Anak Usia Dini Holistik-Integratif. Jakarta: Bidang Sumber Daya Manusia dan Kebudayaan.

Badan Perencanaan Pembangunan Nasional (Bappenas), 2014. Studi Pengembangan Anak Usia Dini di Indonesia. Jakarta: Bappenas.

Chasanatun, Fida, Ervan Johan Wicaksana, Sofia Nur Afifah, 2016. Pemberdayaan Pos Pendidikan Anak Usia Dini dan Wahana Dolanan Mendidik Karaktek Bagi Anak Usia Dini Di Kabupaten Madiun. Jurnal Terapan Abdimas, I (1), hlm. 23-25.

Data Pokok Pendidikan PAUD, 2013. Direktorat Pembinaan Pendidikan Anak Usia Dini.

Dwi, Sigit Handoko dan Achmad Rifa'I, 2014. Penyelenggaraan Program di Pos Pendidikan Anak Usia Dini Cinta Ibu di Desa Pangempon Kecamatan Bawang Kabupaten Batang. Journal of Non Formal Education and Community Empoerment, III (2), hlm 58-64.

Fasli Jalal, 2009. Pengaruh Gizi dan Simulasi Psikososial terhadap Pembentukan Kecerdasan Anak Usia Dini: Agenda Pelayanan Tumbuh Kembang Anak Holistik-Integratif. Padang: Universitas Andalas.

Kementerian Pendidikan dan Kebudayaan. 2013. Norma, Standar, Prosedur, dan Kriteria Petunjuk Teknis Penyelenggaan Pos Pendidikan Anak Usia Dini. Jakarta: Direktorat Jenderal Pendidikan Anak Usia Dini, Nonformal dan Informal.

Kurniawati, Erna Pamungkas, 2011. Peran Serta Dan Keterlibatan Masyarakat Dalam Penyelenggaraan Pos Pelayanan Terpadu Terintegrasi Pendidikan Anak Usia Dini Di Kecamatan Kalasan. Skripsi. Yogyakarta: Program Studi Manajemen Pendidkan Jurusan Administrasi Pendidikan, Fakultas Ilmu Pendidikan, Universitas Negeri Yogyakarta.

Larasati, Theresiana Ani. Pemanfaatan Nilai-nilai Luhur Warisan Budaya Bangsa Dalam Pendidikan Anak Usia Dini.

http://widyariset.pusbindiklat.lipi.go.id/index.php/widyariset/article/viewFile/140/134

Nuryana, Laela, 2011. Peranan Kader Pos Pendidikan Anak Usia Dini dalam Pembinaan Pendidikan Anak Usia Dini di Desa Kalikangkung Kecamatan Pangkah Kabupaten Tegal. Skripsi. Semarang: Universitas Negeri Semarang. http://lib.unnes.ac.id/11726/ diakses 15 November 2015. 
Pusat Penelitian Kebijakan, 2013. Kajian Akses dan Mutu Pendidikan Anak Usia Dini. Jakarta: Pusat Penelitian Kebijakan, Badan Penelitian dan Pengembangan Pendidikan dan Kebudayaan.

Siswanto, Hadi, 2012. Pendidikan Kesehatan Unsur Utama Dalam Pendidikan Anak Usia Dini. Jurnal Cakrawala Pendidikan, XXXI (2), hlm. 305-322.

Suprihati, Sri, 2013. Peranan Pos Pendidikan Anak Usia Dini Dalam meningkatkan Pendidikan Anak Pada Kleuarga Pra Sejahtera di RW 09 Keluarahan Setiamanah Kecamatan Cimahi Tengah. Jurnal. http://publikasi.stkipsiliwangi.ac.id/files/2013/01/Jurnal-SriSuprihati-10030297_fix.pdf

Unicef, 2012. Ringkasan Kajian Pendidikan dan Perkembangan Anak Usia Dini. Jakarta: Unicef.

Wijayanti, Asri, 2012. Politik Pendidikan: Studi Tentang Pendidikan Anak Usia Dini-PosPAUD Terpadu (PAUD - PPT) Kota Surabaya. Jurnal Politik Muda, I (1), hlm. 129144. 